\title{
Exploration on the Application-oriented Talent Training Mode of Biological Engineering
}

\author{
Yan Guo, Changsheng Qiao, Dongguang Xiao, Min Wang, Shiru Jia, \\ Ning Chen, Zhilei Tan \\ College of Biotechnology, Tianjin University of Science \& Technology, Tianjin, China \\ Email: Guoyan@tust.edu.cn
}

Received 2012

\begin{abstract}
Aiming at the existing problems on professional talent training mode of bio-engineering in China ,with the guidance of scientific concept of development ,combining with the development status and trends, talent training objectives and mode of bio-engineering industry in China, basing upon the district of Binhai new area, This paper introduces the useful explorations on professional bio-engineering talent training mode of College of Biotechnology in Tianjin University of Science \& Technology.
\end{abstract}

Keywords: Biological Engineering; Talent Training Mode; Practical Ability

\section{Introduction}

The contents of bio- engineering is taking advantage of the combination of biological system, applied biology, chemistry and engineering technology, transforming and designing the biological structure and function according to the human need, in order to provide technologies of various of product for human need on the method of more economical, more efficient and a large scale. It's the key technology of biological technological achievements towards the industrialization. Review of China's bio-engineering professional education in 10 years, it should be recognized that the rapid development of bio-engineering industry, surge in demand for professionals in biological engineering. So talent training of biological engineering should be moderate in advance to ensure that the talent supply from source, but also pay attention to an appropriate scale, should not over supply. At the present, there are universal problems of biological engineering students as bad beginning ability and lack of innovation ideology, so our college proposed the talent training ideas as "enhance practice, value innovation, and develop personality". It is aiming at training the senior talent of engineering and technical who has good problem solving ability, strong creative consciousness, and high scientific literacy. Because of the features of strong engineering application of biological engineering, it requires students to not only grasp basic theory of biology, but also to accept strictly practical training, to enhance and ensure the teaching quality.

\section{Formulate the Training Targets}

Biological engineering is an important part of high-tech biotech which our focus on the development of high and new technologies in China. This profession is the system which produce the materials that human need or applied to industrial production through special features of modern engineering techniques and use of biological (microbial and plant and animal cells). It developed with the combination of traditional fermentation and modern genetic engineering, cell engineering technology. The experimental area is located in the core area of
Tianjin Binhai New Area, giving full play to regional advantages of Binhai New Area and seizing the opportunity. This experimental area which is based on the Binhai New Area serviced the Bohai Ring and radiated effect in Northwest, Northeast, and North China aiming at training high-level engineering and technical talent who has good problem solving ability, strong creative consciousness, and high scientific literacy in the field of production and technology management, quality control, product development, scientific research and engineering design. Enable students to have a solid foundation of knowledge, true judgment and ability to solve practical problems. These students should also have good communication skills, a spirit of cooperation and some commercial and administrative leadership. What's more, they should be the innovative talent who have lifelong learning skills and habits, be able to adapt and capable of the changing occupational requirements.

\section{Adjustment and Reform of Training Program}

\section{Adjust the Curriculum System and Widen Specialty Ranges}

According to the development tendency of biological engineering, the traditional characteristics of our school and market requirements of bio-engineering talent, we aim to enhance general education, strengthen the foundation, widen specialty range of the students, and improve students' creative potential, adaptability and flexibility of employment. We aim to train innovative biological engineering talent who have solid foundation in the professional fields of biotechnology and engineering, bio-pharmaceutical engineering, food science and engineering, environmental engineering, marine science, and many other engineering disciplines by means of enhance students' professional basis engineering foundation and basic skills training.

Due to the adjustment of original curriculum system from microbial system based system to the entire biological systems, including enzymes, animal cells and plant cells, we added basic biology, cell engineering courses. On the basis of original major, we appropriately added the upstream technologies (such as 
molecular biology, genetic engineering and other courses)and downstream processing (such as bioseparation engineering courses).

Establishing and improving the engineering training system which consists of curriculum design of principles of chemical engineering and bioengineering, biological engineering equipment and biofactory design, we aim to strengthen students' engineering design capabilities. We added biological analysis experimental into biotechnology experiment and combined with raw materials testing, process testing, product testing and bio-technology experiment. It's only enhanced the practical effect of the experiment, but also exercise the students' experimental operation capability, as well as the ability of analyze and solve problems. According to the needs of the society, we will further enhance the professional direction, and students' interest as well as professional specifics to enable students to adapt to market requirements on the basis of strengthens basic education.

\section{Improving the Practice Teaching and Strengthening Project Ability Training}

"Practice is the foundation of engineering" has become the consensus of the international higher engineering education, coupled with the development of China's economic requires a lot of high-quality innovative engineering and technical talent of bio-engineering specialty, so we should keep pace with the times and changing concepts which aim to raise high-quality engineering and technical talent with a strong sense of innovation. We will also establish innovative bio-engineering teaching idea that" practical teaching is as important as and theory teaching" and "practice is the foundation of engineering professionals”. We will correct understand the role of practical teaching on the training of innovative talent and fully affirm the significant of practical teaching in bio-engineering undergraduate education, so the reform and development of biological engineering practical teaching should be promoted.

Practical teaching system which consists of the course experiment, internship, curriculum design, large professional experiment and graduation practice will be further improved. The practical teaching mode will also be changed from unit operational experiments to professional comprehensive test and finally to pilot-scale continuous production, from single equipment design to complex system design.

Basic experimental skills training of course experiment should be strengthened, increase the proportion of design and comprehensive experiments, give full play to the initiative of students, and change the assessment methods and the writing mode of experimental report. Furthermore, the importance of problem analysis and result discussion should be emphasized, students' creative thinking, innovation ability and the ability of analyze and solve problems should be developed.

In order to raise the quality of practice, we will extend the practice time from one week to two weeks. In the first week teachers will introduce the information of large biological discipline for third grade students by the help of electronic equipments. Then in the second week the students will be taken to the factory to get familiar with the production processes, so that students will have a deep understanding of the process, equipment, operation and management. It will also provide them a reference of professional direction for the next step. It is required that students in the process of practice in the factory collect basic data as much as possible under the case of factory's approval in order to lay a foundation for future professional course design.

The practical applicability of curriculum design should be strengthened. The subject of professional curriculum design and basic data (biological engineering equipment and biological plant design) mainly come from production line of the factories, so it has a strong practical applicability and comparability of design results. It will also be able to stimulate students' enthusiasm for learning.

We combined the original experimental teaching courses into the large bio-engineering experiments which will perform for 3 weeks in the 7 th semester. Students are divided into several groups and assigned to the laboratories of every college. The laboratories of every college will use their own advantages to create the professional test derived from scientific research. The unit operational experiments including biological analysis, bio-reaction engineering principles and bioseparations engineering will be merged into large process experiment. The students not only obtained basic operational training of bio-engineering and improved the practical abilities, but also enhanced the ability of problem finding and problem solving.

The period of graduation should be emphasized. The key of graduate design and thesis is to standardize the topic, so the regulation of "one person, one question" should be strictly performed. The topic should be chosen close connected with the training objectives which need to combine with the theoretical and professional knowledge, so it requires students to complete the design and thesis independently under the guidance of teachers.

\section{Propel the Establishment of Personalized Talent Training Mode}

In order to meet students' individual development requirements and perform "Individualized" teaching concept , we established individualized talents training mode which including professional direction selection, current trends introduction of professional field, innovative experiment open system and entrepreneurial training.

The first level: On the basis of strengthen the basic education, we established different major fields on bio-engineering for the senior students after finishing public elementary courses, especially the fourth grade students, according to the students' interest and the social demand direction of talent. Thus students can choose different major direction according to their personal actual situation and interest under the guidance of professors. We aim to determine the students' individual training objectives and set up training plans which varies from person to person. We will also highlight the specialty on talent training in order to cultivate talent with applied competence for the society.

The second level: We established multi-disciplinary development forefront elective courses in order to introduce the latest technology developments domestic and abroad, let the students know the forefront theory of bio-engineering, teach production processes of variety of main products in bio-engineering and the latest technology and development prospects. It also requested students to write special report of bio-engineering development according to their interests.

The third level: We established the innovative experiments. 
In order to develop students' practical ability and scientific literacy, we allocate some students into different laboratories by following the two-way choice principle in the third year of students, so that they can use spare time for research projects. The subject source can become the part of research project. Or the student teams can put forward a proposal, and then turn to laboratory work after the recognition of the professors.

The fourth level: the entrepreneurial training course for students is on the basis of the internal training base. Under the guidance of professors, the students' entrepreneurial team, taking training base as the platform, simulates the enterprises of production and operation management in a certain time.

\section{Strengthen the Construction of Internal and External Students' Training Base and Enhance the Social Service Function}

The internal training base which consists of 500L anaerobic fermentation system and 500L Anaerobic fermentation system has the advantages of anytime, convenience and efficiency. The internal training base is open to the students and public. The technology testing and technology innovation activities made by students and companies should be allowed and supported. The internal training base is on the basis of typical biological products. The students gain practice and training through participated in research projects, pilot experiments and production process. Thus the internal training base will become the platform of practice teaching, as well as the platform of new products, new technology and scientific research in order to serve the society. On the other hand, we will establish the long-term cooperation with enterprises and found stable external training bases. The cooperation can be varied, such as the school can help enterprises to solve some problems in the production process, develop new products, train the required talents and open the laboratories. Otherwise, the enterprises, can offer internships for students, as well as it can be and the test base pilot of new product development for the school. Through the way of combination with production, teaching and research, the school can provide technical services for enterprises, so that students can learn the typical biological production process from the advanced domestic enterprises. Moreover, the students will gain comprehensive upgrade on knowledge structure and practical ability.

Giving full play to the function of both internal and external training bases, it not only could solve the problems of training bases, but also have great significance in promoting the combination of teaching and scientific research, as well as the rapid transformation of scientific research products.

\section{Conclusion}

According to the training objectives of the engineering talent, the training of bio-engineering talent should embody the principle of coordinated development among knowledge, capacity, and quality. Appropriate knowledge system should be established, so that the quality education of practical skills and engineering capabilities will be performed. And design and construction of knowledge structure should be strengthened, so that each knowledge module constitutes an appropriate training system. The teaching concept of "practical teaching is as important as and theory teaching" and "practice is the foundation of engineering professionals" should be established. And we also focus on basic theory, engineering knowledge and experimental teaching, so that students' capabilities of strong analyzing and solving engineering problems will be boosted. The adjustments of curriculum system should combine with the characteristics of regional economic development and under the guidance of social needs on training mode reform. On the occasion of large biological disciplines, the culture caliber should be broadened, so that innovative talent training mode which including people-oriented, individualized, flexible design of curriculum system and personalized learning will be established. Practical teaching system which consists of the course experiment, internship, curriculum design, large professional experiment and graduation practice will be further improved. The practical teaching mode will also be changed from unit operational experiments to professional comprehensive test and finally to pilot-scale continuous production, from single equipment design to complex system design. The combination between teaching and scientific research should be promoted in order to achieve the goal of scientific research assist teaching.

\section{REFERENCES}

Wells,John Henry,and Taylor. "First principles in biological engineering education,” Resource: Engineering and Technology for Sustainable World, v 3, n 4, Apr 1996; ISSN: 10763333.

Riley,and Mark R.“New designs on teaching biological engineering.” ASEE Annual Conference Proceedings, p11043-11047, 2002, 2002 ASEE Annual Conference and Exposition:Vive L'ingenieur; ISSN 01901052.

Christy,AnnD;Lima Marybeth,andAlocilja,Evangelyn C. "The use of student portfolios to enhance learning, industrial ties, and accreditation in biological engineering education” 2000 ASAE Annual International Meeting, Technical Papers: Engineering Solutions for a New Century, v 2, p 5227-5237.

常景玲, 李兰, 郭丹钊, 张志宏, 华承伟.生物工程实验课程教学改 革探索 $[\mathrm{J}]$.实验科学与技术,2008(4):78-79.

贾士儒,许春英,乔长晟. 搞好工科专业实践性教学的一点体会 $[\mathrm{J}]$. 天 津师范大学学报（增刊）,2007::249-250. 